FACTA UNIVERSITATIS

Series: Working and Living Environmental Protection Vol. 18, № 1, 2021, pp. 39 - 47

https://doi.org/10.22190/FUWLEP2101037R

Review Paper

\title{
WORKER SAFETY DURING EXCAVATION AND TRENCHING CONSTRUCTION WORK
}

\author{
UDC 331.45:624.134
}

\section{Jasmina Radosavljević, Ana Vukadinović, Amelija Đorđević}

\author{
University of Niš, Faculty of Occupational Safety in Niš
}

\begin{abstract}
Earthworks are the integral part of any construction work in civil engineering and building construction. The construction activities performed during earthworks include the following: excavation, earthmoving, earth transport, and earth compaction. During earthworks, the excavation site is subject to harmful, flammable, or hazardous materials, damage to underground installations, the collapse of the earth, and many more risks. Therefore, construction work for trenching and excavation requires the implementation of adequate safety measures. This paper discusses the safety measures for workers during earthworks that involve excavations up to and exceeding one meter in depth.
\end{abstract}

Key words: occupational safety, construction work, trenching and excavation

\section{INTRODUCTION}

Due to a large number of persons involved in construction work, the complex interrelations, and the connections between materials, tools, machinery, and operations, risk identification and quantification in construction are much more complex than in other industries. Construction workers are subject to occupational injuries, which are often serious and even fatal, occurring mostly due to inadequate work conditions and the lack of proper personal protective equipment.

Earthworks are the integral part of any civil engineering and building construction work. There is no type of construction work that does not require earthworks, whether as preceding, preparatory, auxiliary, or finishing operations. Earthworks can be performed on the soil surface, underneath the surface, or under water.

The construction activities during earthworks include the following:

- excavations: ground (surface), subsurface (tunnelling), under water;

- removal and transport of excavated material to a designated location;

- compaction of the removed earth to design compactness.

Received November 18, 2020 / Accepted April 5, 2021

Corresponding author: Ana Vukadinović

University of Niš, Faculty of Occupational Safety, Čarnojevića 10a, 18000 Niš, Serbia

E-mail: ana.vukadinovic@znrfak.ni.ac.rs 
Surface excavation includes shallow surface excavation, wide excavation, benching excavation, foundation pit excavation, excavation for foundations, trench excavation, and channel excavation.

The following detrimental occurrences are likely during construction work on excavations:

- presence of harmful, flammable, and hazardous materials;

- damage to underground installations (water supply, sanitation, district heating, gas lines, etc.);

- collapses, slips, and cave-ins (e.g. if the earthworks are performed near a building from which materials and other objects can fall);

- presence of groundwater.

Before and during excavation, the soil and the most risk-prone locations are checked for the presence of harmful, flammable, and hazardous materials. If the earthworks are performed at a location that contains various public installations, such as electrical, telephone, water and sanitation, or other installations, they are performed according to the instructions previously obtained from the utility company in charge of maintaining specific installations. If the earthworks are performed near a building from which materials and other objects can fall and endanger the safety of the workers, it is necessary to ensure that all the safety measures are taken before and during the excavation. Safety measures also have to be implemented if the excavation is performed near or on roads, where pedestrians or moving vehicles can endanger the workers.

\section{SAFETY MEASURES DURING EARTHWORKS IN TRENCHING AND EXCAVATION}

\subsection{Earthworks in trenching and excavation up to 1 meter in depth}

During earthworks on an excavation up to the depth of 1 meter from the surface, no additional occupational safety measures are required if the soil material remains in balance at a given construction slope when its natural moisture changes in contact with air, when there is groundwater present, or when the site is affected by surface water and vibrations from road traffic or construction machinery.

Additional occupational safety measures are also not required if there is no movement of the surrounding soil mass and no threats to the nearby buildings and the surrounding area. Likewise, additional safety measures are not required if there are no above ground or underground installations within the work zone.

\subsection{Earthworks in trenching and excavation exceeding 1 meter in depth}

When earthworks are performed on excavations exceeding the depth of $1 \mathrm{~m}$, the excavated earth is subject to collapsing. The collapse can be prevented with the following methods:

- sloping excavation at an angle that is lower than the angle of the slip circle of the material;

- benching excavation, if the material can be vertically stable at lower heights;

- trench shoring (formwork with its internal elements);

- use of retaining wall support. 


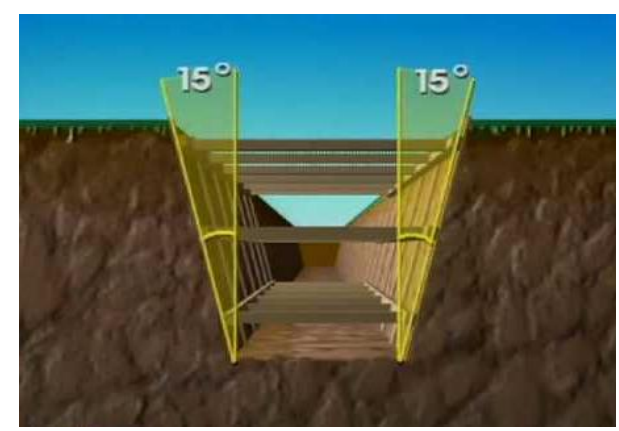

(a)

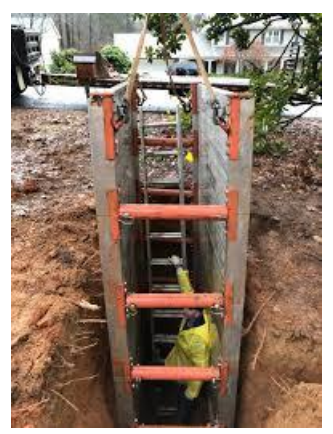

(b)

Fig. 1 Securing trench walls against collapse: (a) Sloping excavation (b) Shoring

Trenching and excavation up to $3.0 \mathrm{~m}$ deep can be performed by creating unsupported free slopes [1]. Regardless of their depth, sloped unsupported excavations require slope protection against erosion using geothermal membranes and slope stabilization using vacuum drainage. If slopes are not adequately protected or stabilized, there is a risk of slides and mass flows of the soil. If the slope is above groundwater level, it can be at a $45^{\circ}$ angle without any detailed verification of its safety. The slope height and angle depend on the plasticity and strength of the soil. Low-plasticity soils are prone to flows, particularly if they contain sand or silt. [1]

Wall support structures are utilized in the construction of infrastructure in large cities, especially in the excavated space for underground rails, but also in underground car parks, shopping centres, various warehouses, and the like.

Figure 2 shows some of the common wall support schemes used for stabilizing excavations.

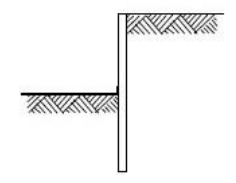

a)

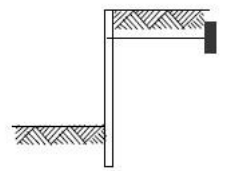

f)

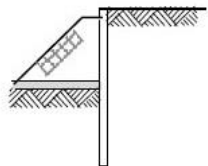

b)

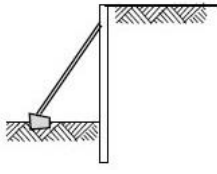

c)

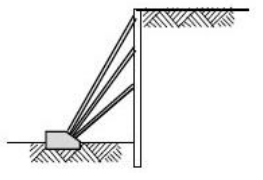

d)

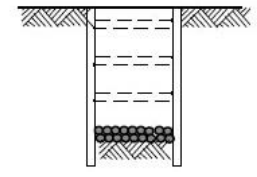

e)

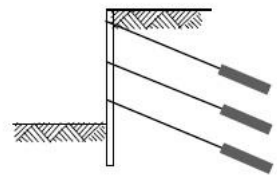

g)

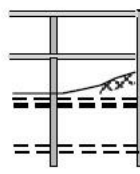

h)

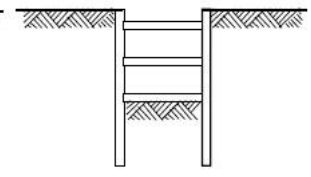

i)

Fig. 2 Common types of wall support schemes: (a) Cantilever wall; (b) Berm and slab; (c) Single-propped wall; (d) Multi-propped wall; (e) Soilcrete slab; (f) Tie-back wall; (g) Ground anchors; (h) Top-down construction; and (i) Braced excavation [1] 
Wall support systems for ensuring excavation stability include retaining walls with shores or stays, diaphragms, steel and concrete slabs, sheet piles, grouting, and others. The support structures differ according to design technology, type of material used, and stiffness and flexibility.

The choice of the excavation type depends on the type of soil, presence and depth of groundwater, the proximity of existing structures/buildings and roads, excavation depth, excavation phases, maximum allowed deformation, etc.

Structures used to secure excavations deeper than $1.0 \mathrm{~m}$ comprise the formwork and the internal elements. The formwork is placed so as to sustain the pressure from the earth excavation walls and to transfer it to the internal shoring elements. The formwork must not be sparsely distributed because the surrounding earth could collapse into the trench through the spacings. If the soil is loose, the formwork elements are pressed against one another, while the soil cavities are filled on the external portion of the formwork in order to prevent formwork deformation due to earth pressure.

Horizontal internal shoring elements must not change their position under load, which is why they need to be securely connected and, if necessary, horizontal columns are placed between the horizontal longitudinal girders. Shoring is conducted gradually and simultaneously with the excavation, from the top edge downward by placing the formwork and the internal shoring elements while removing the excavated material. The formwork should protrude at least $20 \mathrm{~cm}$ above the excavation top edge to prevent materials, tools, and other objects from falling into the excavation.
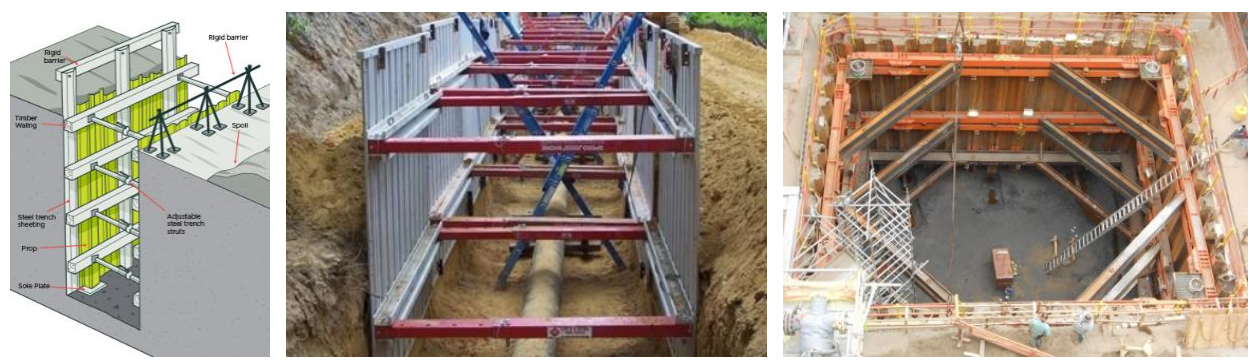

Fig. 3 Excavation shoring with propped formwork

The formwork is removed in the reverse order from the placement, simultaneously with the backfilling. The material used for the shoring must comply with the technical requirements and standards for load-bearing structure materials.

The excavation width is specified such that the lowest cross-section width of the clean opening between the shoring elements is $60 \mathrm{~cm}$. Places or fields for vertical lowering and lifting of materials through the shoring require separate shoring and adjustments for uninterrupted movement of objects, while their dimensions and the distance between them are determined according to the requirements of the technological process.

During construction work at an excavation, the angle between the excavation sides and the horizontal plane must be at least $90^{\circ}$ measured from inside the excavation. It is also prohibited to undermine the excavation without proper safety measures in place when there is an enclosed mound of earth on top of it. 
When the excavation is done on soils prone to cave-ins, the work can proceed only after the previously excavated earth is completely secured against a cave-in. The excavated material is to be moved away from the excavation edge so as to avoid its potential collapse into the trench.

With every excavation and trenching work, the involved workers have to be provided with safe descent and ascent. If the excavation does not exceed the depth of $3.0 \mathrm{~m}$ in relation to the ground level, descent and ascent can be performed using a ladder secured against movement and falling over, protruding at least $75 \mathrm{~cm}$ above the top edge, and equipped with anti-slip base protection. The distance between the ladders must not exceed $30.0 \mathrm{~m}$. [2,3]

If the excavation goes deeper than $3.0 \mathrm{~m}$, the workers must be provided with adequate steps or ramps for safe descent and ascent. The horizontal distance between the fixed worker access/egress points must not exceed $20.0 \mathrm{~m}$. The ramps or stairways should regularly be cleaned of accumulated mud and treated with anti-icing materials during frost periods. [2,3]

If the excavation exceeds $1.0 \mathrm{~m}$ in depth, it is necessary to prepare an evacuation plan and the equipment to be used for worker evacuation in case of injury or immobility. When a trench is excavated using machinery, machines are also used to simultaneously insert metal shielding into the trench (e.g. a "Krings" trench box or the like), and the workers are allowed to enter the excavation only after it has been secured against a cavein (Figure 4).

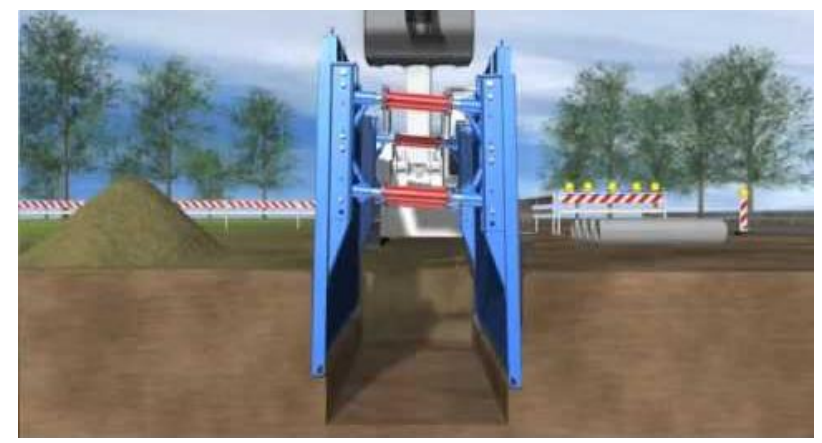

Fig. 4 "Krings" trench box

The removal of earth from the excavation exceeding $2.0 \mathrm{~m}$ requires intermediate floors, which must not rest on the shoring elements but instead have their own support structure. The intermediate floor edges must have protection sides at least $20 \mathrm{~cm}$ in height.

Figure 5 shows the proper and improper placement of excavated material. 

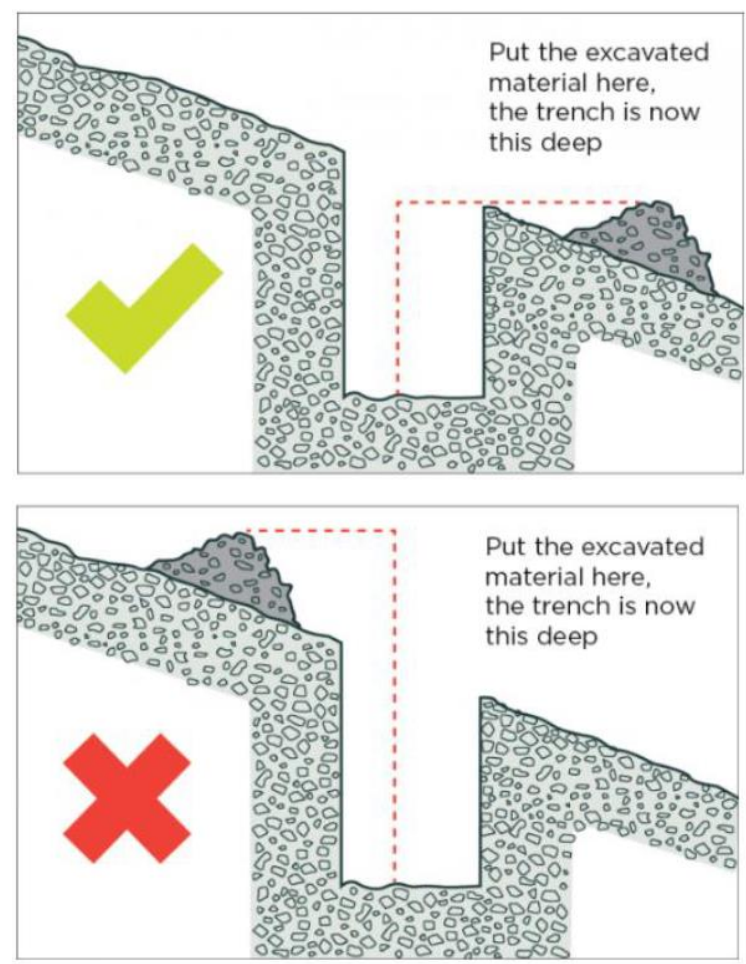

Fig. 5 Proper and improper placement of excavated material

When a construction site shifts its position to occupy and enclose the least space possible, which is the case with trenching for the placement of water and sanitation pipes, the work phases are distributed over shorter periods, and the operations are performed in parallel. If the earthworks are performed in residential areas, the excavated material is immediately transported off-site to avoid pile-ups. Such excavation earthworks sites need to be secured to keep away any incoming vehicles or nearby pedestrians.

During excavation in the immediate vicinity of buildings, roads, or utility poles, the contractor has to prevent any damage, deformation, subsidence, or collapse to these structures and any other events that may threaten the safety of the workers.

Figure 6 shows the collapse of a retaining wall at an unsecured construction site in Zemun, Serbia, when four employees of the Grading construction company from Belgrade lost their lives [4].

Figure 7 shows the retaining wall secured with panels with steel posts unequally distributed in-between, depending on the distance between the wall and the surrounding structures. The retaining wall support system is propped by struts via a horizontal tie beam and a diagonal corner bracing strut [5]. 


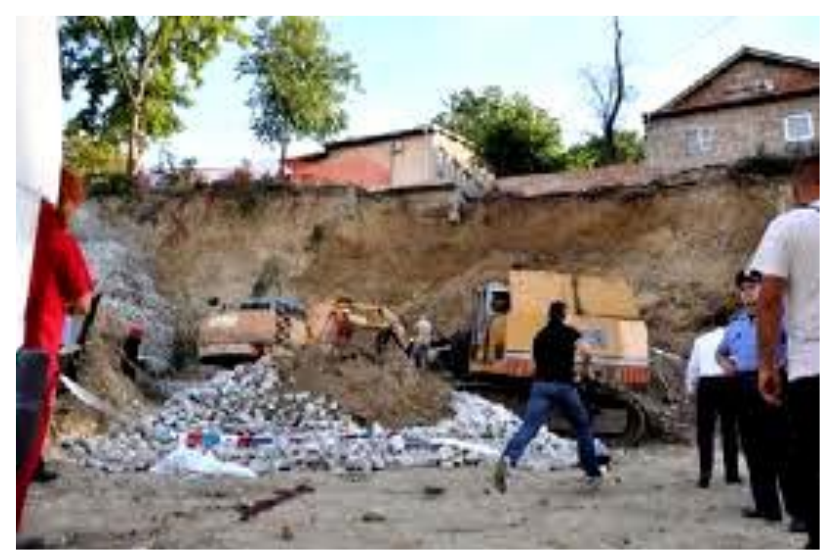

Fig. 6 Retaining wall collapse at a construction site in Zemun, Serbia [2]

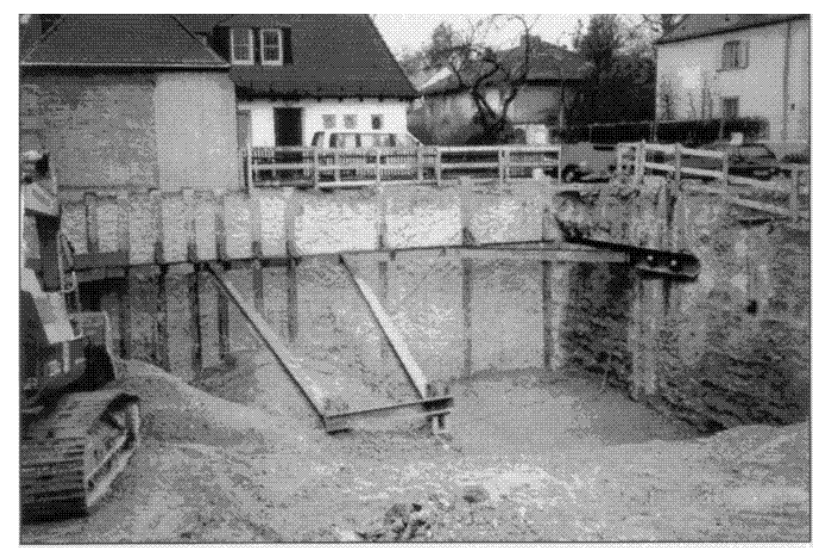

Fig. 7 Securing the retaining wall

\section{Personal Protective EQUiPMENT FOR TRENCHING Workers}

During excavation works, harmful, flammable, or explosive materials are known to be present. Additionally, serious or fatal worker injuries may occur if the earthworks are performed at a site containing electrical, telephone, water and sanitation, and other installations. The excavation work requires strict implementation of prescribed safety measures in order to ensure workers' safety. The safety measures also include the use of personal protective equipment - overalls, helmet, gloves, boots, mask for respiratory protection, and ear plugs [6-10]. 


\section{MACHINE TRENCHING}

Machine trenching requires the implementation of safety measures that will ensure the safety of the machine operators and other workers who move or work near the machines. It is necessary to ensure that non-employees, vehicles, installations, objects, or structures are not present in the danger zone around active machinery, as they could be endangered by the machines or could cause unsafe machine operation.
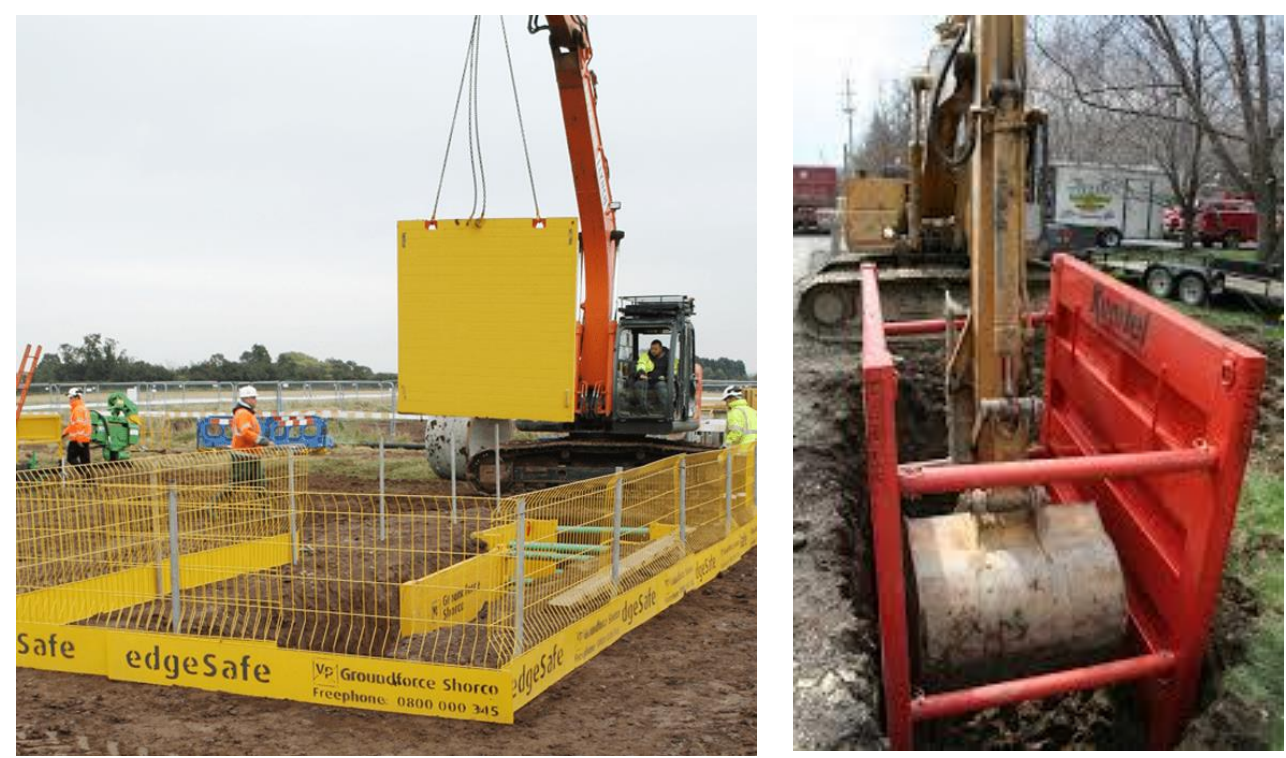

Fig. 8 Construction machinery excavation compliant with all the requirements

Construction machinery used for excavation can be put to use only when all requirements for its safe operation and movement have been met (Figure 8). It implies the provision of safe access, the required free space, a secure space for proper operative positioning, clear lines of sight, etc. On soft, slippery, or steep terrains, as well as on surfaces that can lead to heavy machinery sinking, moving unexpectedly, or becoming unstable, the use of construction machinery is prohibited.

In poor weather conditions with reduced visibility, the machine operator can lose control of the machine, which is why machine operations have to be suspended under such conditions.

\section{CONCLUSION}

During excavation earthworks up to the depth of $1.0 \mathrm{~m}$ from the ground surface, no special safety measures are required if the earth material remains balanced. If the excavation work is performed at depths exceeding $1.0 \mathrm{~m}$, it is necessary to secure the excavation edges against cave-ins. The cave-ins can be prevented using sloping excavation, benching excavation, shoring, or wall support structures. Wall support schemes for excavation stability differ according to design technology, type of material, and their rigidity/flexibility. It is important to 
implement all the required safety measures during excavation earthworks in order to ensure workers' safety, which also includes the use of personal protective equipment.

Acknowledgement: This paper is a result of a research supported by the Ministry of Education, Science and Technological Development of the Republic of Serbia according to contract no. 45103-9/2021-14/200148.

\section{REFERENCES}

1. Kempfert, H. G., \& Gebreselassie, B. (2006). Excavations and foundations in soft soils. https://doi.org/ $10.1007 / 3-540-32895-5$

2. Law on Occupational Safety and Health (Official Gazette of the Republic of Serbia, no. 101/2005, 91/2015, and 113/2017)

3. Regulations on Occupational Safety during Construction Work (Official Gazette of the Republic of Serbia, no. 53/97, 14/09 - state act)

4. Tempus JPHES 158781, Occupational Safety and Health - Degree Curricula and Lifelong Learning Modul 4.0, VTŠ, Niš, 2013.

5. Tanja Roje-Bonacci, Potporne građevine i građevne jame [Retaining Structures and Foundation Pits], Građevinsko-arhitektonski fakultet Sveučilišta u Splitu, 2005.

6. www.volga.co.rs

7. www.hse.gov.uk

8. www.seibl-trade.com

9. www.albo.biz

10. www.pixabay.com

\section{ZAŠTITA RADNIKA PRI IZVOĐENJU GRAĐEVINSKIH RADOVA NA ISKOPU ROVOVA I JAMA}

Zemljani radovi su sastavni deo izgradnje svih objekata niskogradnje i visokogradnje. Građevinske aktivnosti koje se obavljaju prilikom izvođenja zemljanih radova obuhvataju: iskope, premeštanje, prevoz i zbijanje iskopanog materijala. Pri izvođenju građevinskih radova na iskopu može doći do pojave štetnih, zapaljivih i opasnih materija, oštećenja podzemnih instalacija, obrušavanja zemlje itd. Zbog toga se prilikom izvođenja građevinskih radova na iskopu rovova i jama moraju preduzeti odgovarajuće mere zaštite za bezbedan rad. U radu su prikazane mere zaštite radnika prilikom izvođenja zemljanih radova na iskopu do dubine od $1 \mathrm{~m}$ i na dubini većoj od $1 \mathrm{~m}$.

Ključne reči: zaštita na radu, građevinski radovi, iskop rovova i jama. 